\title{
Nigrosome 1 absence in de novo Parkinson disease
}

Matthew Brodsky, MD, David Lahna, BA, Jeffrey Pollock, MD, David Pettersson, MD, John Grinstead, PhD, and William Rooney, PhD

Neurology ${ }^{\circledR}$ 2018;90:522-523. doi:10.1212/WNL.0000000000005128

Figure Comparative brain MRIs of an individual with de novo Parkinson disease and an age-matched control
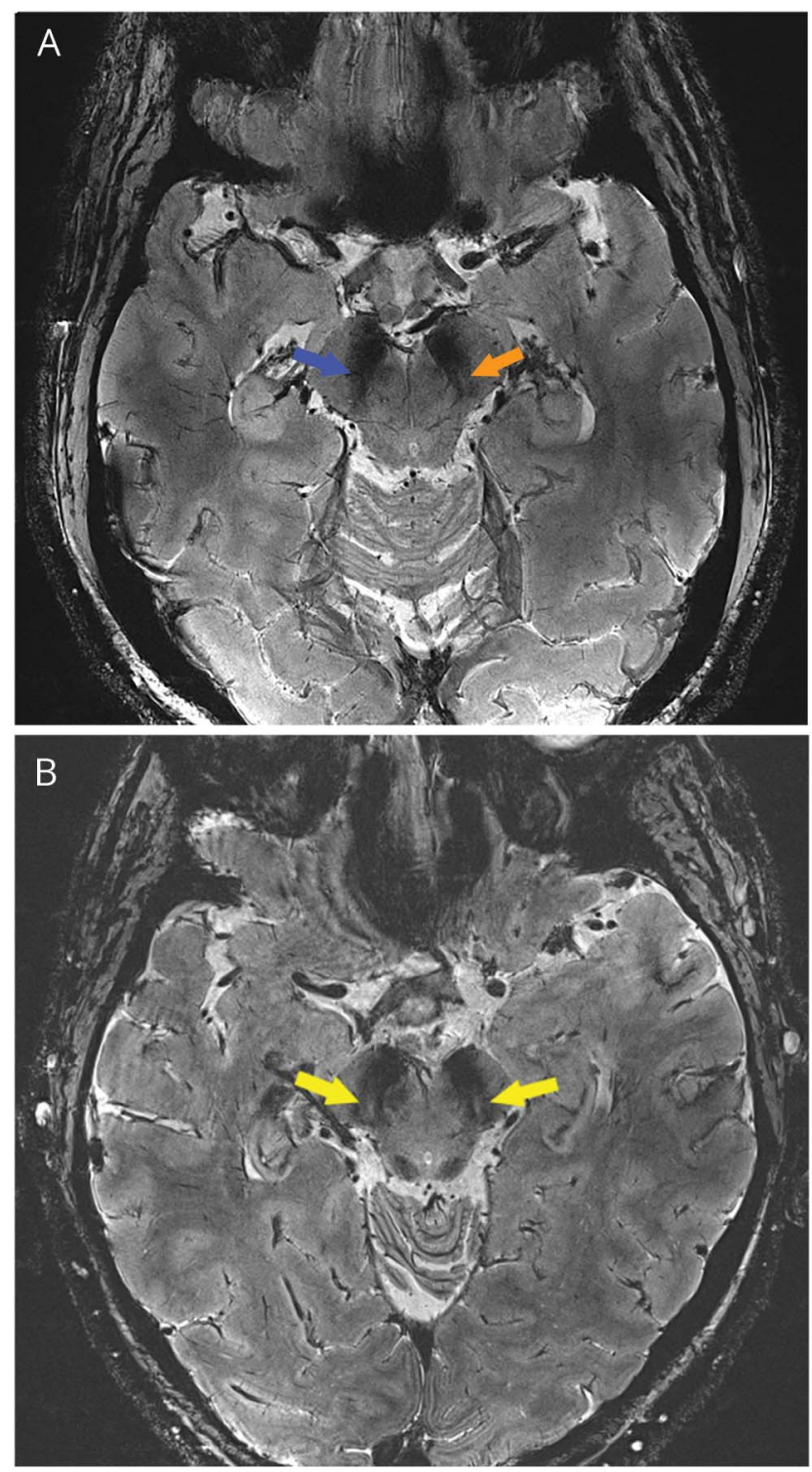

(A) 7T MRI gradient echo sequence axial slice shows nigrosome 1 signal present in the left substantia nigra (orange arrow) and absent in the right substantia nigra (blue arrow). (B) 7T MRI of a healthy 63-year-old is shown for comparison, with normal nigrosome 1 signal present bilaterally (yellow arrows).

\section{Correspondence}

Dr. Brodsky

brodskym@ohsu.edu 
A 63-year-old man with 6 months of mild left hand rest tremor and bradykinesia and subtle left wrist cogwheel rigidity was diagnosed with idiopathic Parkinson disease (PD). The most profound neuronal degeneration in $\mathrm{PD}$ occurs in nigrosome 1 , a lens-shaped substructure of the substantia nigra containing approximately 22,000 cell bodies in each hemimidbrain, measuring $6 \times 6 \times 1 \mathrm{~mm} .{ }^{1,2}$ A 7 T MRI at the caudal level of red nucleus (figure, A) shows nigrosome 1 signal present in the left nigra and absent in the right, consistent with the clinically affected side. 7T MRI of a healthy 63-year-old with normal bilateral nigrosome 1 signal is shown for comparison (figure, B).

\section{Author contributions}

Matthew Brodsky: study concept and design, acquisition and analysis of data. David Lahna: study design, acquisition and analysis of data. Jeffrey Pollock: study design, acquisition of data. David Pettersson: study design, acquisition of data. John Grinstead: study design. William Rooney: study design.

\section{Study funding}

OHSU Research Core Grant.

\section{Disclosure}

The authors report no disclosures relevant to the manuscript. Go to Neurology.org/N for full disclosures.

\section{References}

1. Damier P, Hirsch EC, Agid Y, Graybiel AM. The substantia nigra of the human brain II: patterns of loss of dopamine-containing neurons in Parkinson's disease. Brain 1999;122:1437-1448.

2. Blazejewska A, Schwarz ST, Pitiot A, et al. Visualization of nigrosome 1 and its loss in PD. Neurology 2013;81:534-540.

\section{Disputes \& Debates: Rapid online correspondence}

The editors encourage comments on recent articles through Disputes \& Debates:

Access an article at Neurology.org/ $N$ and click on "COMMENT" beneath the article header. Responses will be posted within 3 business days.

Before submitting a comment to Disputes \& Debates, remember the following:

- Disputes \& Debates is restricted to comments about studies published in Neurology within the last eight weeks

- Read previously posted comments; redundant comments will not be posted

- Your submission must be 200 words or less and have a maximum of five references; reference one must be the article on which you are commenting

- You can include a maximum of five authors (including yourself)

\section{Get 10 AAN Practice Management Webinars for Less than \$19 Each}

The AAN is dedicated to helping neurologists improve their practices and delivery of quality care to their patients. The AAN's Practice Management Webinars provide the valuable insights and tools you need to navigate through the ever-changing health care landscape — and receive year-end CME credits!

Purchase webinars individually for $\$ 99$ each, or subscribe to the complete series of 2018 webinars for only \$189-that's less than $\$ 19$ per webinar! See the list of webinars and subscribe at AAN.com/view/pmw18. 


\title{
Neurology
}

\author{
Nigrosome 1 absence in de novo Parkinson disease \\ Matthew Brodsky, David Lahna, Jeffrey Pollock, et al. \\ Neurology 2018;90;522-523 \\ DOI 10.1212/WNL.0000000000005128
}

This information is current as of March 12, 2018

\section{Updated Information \& Services}

References

Subspecialty Collections

Permissions \& Licensing

Reprints including high resolution figures, can be found at: http://n.neurology.org/content/90/11/522.full

This article cites 2 articles, 1 of which you can access for free at: http://n.neurology.org/content/90/11/522.full\#ref-list-1

This article, along with others on similar topics, appears in the following collection(s):

\section{MRI}

http://n.neurology.org/cgi/collection/mri

Parkinson's disease/Parkinsonism

http://n.neurology.org/cgi/collection/parkinsons_disease_parkinsonism

Information about reproducing this article in parts (figures,tables) or in its entirety can be found online at:

http://www.neurology.org/about/about_the_journal\#permissions

Information about ordering reprints can be found online:

http://n.neurology.org/subscribers/advertise

Neurology ${ }^{\circledR}$ is the official journal of the American Academy of Neurology. Published continuously since 1951, it is now a weekly with 48 issues per year. Copyright () 2018 American Academy of Neurology. All rights reserved. Print ISSN: 0028-3878. Online ISSN: 1526-632X.

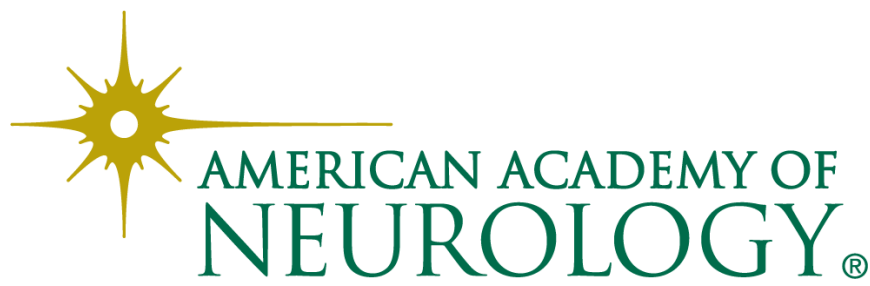

